Бойко Олена Петрівна кандидат наук з державного управління, докторант кафедри публічного управління та публічної служби Національної академії державного управління при Президентові України, вул. Антона Цедіка, 20, м. Київ, 03057, тел.: (044) 481-21-55, e-mail: brvkiev2019@gmail.com, http://orcid.org/0000-0003-3718-1039

\title{
АСОЦАЦІЇ ОРГАНІВ МІСЦЕВОГО САМОВРЯДУВАННЯ НАЦІОНАЛЬНОГО РІВНЯ: ПРАВО ТА СПРОМОЖНІСТЬ
}

Анотація. Стаття присвячена дослідженню асоціацій органів місцевого самоврядування, що $є$ формалізацією взаємодії органів публічної влади та підгрунтям відповідності діяльності органів місцевого самоврядування задекларованим ними цілям. Право органів місцевого самоврядування при здійсненні повноважень створювати асоціації для виконання завдань, що становлять спільний інтерес, закріплено Європейською хартією місцевого самоврядування. Таке право закріплено на національному рівні європейських країн. В Україні питання асоціацій органів місцевого самоврядування регламентується спеціальним Законом України "Про асоціації органів місцевого самоврядування". Асоціації мають за мету, в першу чергу, відстоювання інтересів своїх членів через діалог на загальнонаціональному та місцевому рівнях. Організаційно-правова форма $\epsilon$ різною, незалежно від державного устрою, особливостей місцевого самоврядування. Право на асоціації реалізується в залежності від історії розвитку таких асоціацій. У цілому типовими характеристиками асоціацій є: добровільне та відкрите членство (як правило); правова регламентація діяльності статутними нормами; рівність права голосу, а рішення приймаються більшістю (як правило); добровільні членські внески; автономія і незалежність; добровільна робота та адвокація / представництво; можливість бути постачальниками послуг для своїх членів. Як правило, основна організаційна форма - юридичні особи. Організаційно-правове забезпечення розвитку асоціацій місцевого самоврядування в Україні має бути науково обгрунтований 3 урахуванням зарубіжної практики. Право на асоціації реалізується у спроможність за умови не лише достатнього правового регулювання, а й достатнім обсягом повноважень та належним ресурсним забезпеченням. Основними умовами спроможності асоціацій $\epsilon$ не лише ефективність організаційно-правових засад, а й мотивація членів об`єднання та 
співпраця членів в рамках асоціації. Важливим фактором є достатнє ресурсне забезпечення, ефективна кадрова політика. Спроможність асоціацій органів місцевого самоврядування напряму залежить від всієї системи державної політики та забезпеченні прав місцевого самоврядування на самовизначення щодо добровільного об єднання органів місцевого самоврядування.

Ключові слова: асоціації, органи місцевого самоврядування, спроможність, об єднання, міжмуніципальна співпраця, повноваження.

Boyko Olena Petrovna Candidate of Sciences in Public Administration, Doctoral Student of the Department of Public Administration and Public Service of the National Academy of Public Administration under the President of Ukraine, Anton Tsedik St., 20, Kyiv, 03057, tel: (044) 481-21-55, e-mail: brvkiev2019@gmail.com, http://orcid.org/0000-0003-3718-1039

\section{ASSOCIATIONS OF LOCAL GOVERNMENT BODIES OF THE NATIONAL LEVEL: LAW AND CAPACITY}

Abstract. The article is devoted to the study of associations of local governments, which is a formalization of the interaction of public authorities and the basis for the compliance of local governments with their declared goals. The right of local selfgovernment bodies, in the exercise of their powers, to establish associations to carry out tasks of common interest is enshrined in the European Charter of Local SelfGovernment. This right is enshrined at the national level of European countries. In Ukraine, the issue of associations of local self-government bodies is regulated by a special Law of Ukraine "On Associations of Local Self-Government Bodies". Associations aim, first and foremost, to defend the interests of their members through dialogue at the national and local levels. The organizational and legal form is different, regardless of the state system, the features of local self-government. The right to association is exercised depending on the history of development of such associations. In general, the typical characteristics of associations are: voluntary and open membership (usually); legal regulation of statutory norms; equality of the right to vote, and decisions are made by a majority (usually); voluntary membership fees; autonomy and independence; voluntary work and advocacy / representation; the opportunity to be service providers for its members. As a rule, the main organizational form - legal entities. Organizational and legal support for the development of local self-government associations in Ukraine should be scientifically substantiated taking into account foreign practice. The right to association is realized in capacity under the condition not only of sufficient legal regulation, but also of the scope of powers and sufficient resources. The main conditions for the capacity of associations are not only the provision of 
organizational and legal principles, but also the motivation of members to unite and the cooperation of members within the association. An important factor is sufficient resources, effective personnel policy. The ability of local self-government associations directly depends on the entire system of state policy and ensuring the rights of local self-government to self-determination in relation to the voluntary association of local self-government bodies.

Keywords: associations, local governments, capacity, associations, intermunicipal cooperation, powers.

Постановка проблеми. Асоціації органів місцевого самоврядування в Україні мають статус місцевих та всеукраїнських та мають тривалу історію розвитку 3 перших років державної незалежності країни. Асоціації органів місцевого самоврядування є інституціюванням взаємодії органів публічної влади, $\epsilon$ позитивним чинником забезпечення відповідності діяльності органів місцевого самоврядування задекларованим ними цілям. Саме тому подальший інстутиційний розвиток асоціацій місцевого самоврядування в Україні має бути обгрунтований зарубіжною практикою та змістом функцій, повноважень i повнотою організаційно-правового механізму діяльності.

Аналіз останніх досліджень і публікацій. Окремі питання функціонування асоціацій органів місцевого самоврядування згадано у наукових працях М. Баймуратова, О. Батанова, В. Кампа, В. Кравченка, Н. Нижник, та ін. Вагомим внеском у дослідження засад міжмуніципального співробітництва є праці Г. Борща, А. Гука, О. Ігнатенка, В. Купрія, В. Толкованова. Питанням діяльності та повноважень асоціацій органів місцевого самоврядування присвячені окремі роботи І. Бодрової, С. Крушановського, П. Любченка, В. Полтавець, І. Сало та інш. Проте потребують додаткового дослідження організаційно-правові засади діяльності асоціацій органів місцевого самоврядування.

Мета статті - право та спроможність асоціацій органів місцевого самоврядування національного рівня.

Виклад основного матеріалу. В аналітичній доповіді Центру Разумкова “Конкурентоспроможність регіонів України: Стан і проблеми” визначено, що асоціації органів місцевого самоврядування $\epsilon$ організаційно-правовою формою участі громадян в управлінні державою через обраних депутатів та посадових осіб органів місцевого самоврядування [1, с.15-19]. За висновками С. Крушановського, “інституціональне призначення асоціацій органів місцевого самоврядування пов'язане $з$ певними суспільними потребами, для задоволення яких створюються організації з визначеними функціями, які, як правило, фіксуються у законодавстві у вигляді певних повноважень” [2, 82-83]. Аналізуючи характеристики асоціацій, як об’єднань органів місцевого самоврядування, I. Бодрова виокремлює 
організаційні характеристики (добровільність; складну організаційну природу; членство публічно-владних органів; єдність структури; самоорганізація, саморегулювання та самоврядування; некомерційність діяльності; статус юридичної особи) та функціонально-цільові характеристики (це суб'єкти відносин місцевого самоврядування; мають публічно-правові інтереси членів; обмеження прав 3 вирішення питань місцевого значення, відсутність делегованих повноважень; утворення добровільних об’єднань не тягне будь-яких змін у системі місцевого самоврядування; функціонують за дозвільним принципом правового регулювання) [3].

У висновках аналізу особливостей організаційно-правового забезпечення діяльності асоціацій органів місцевого самоврядування національного рівня в країнах Європейського Союзу, підготовленому швейцарсько-українським проектом "Підтримка децентралізації в Україні“ DESPRO серед іншого зазначено, що асоціації органів місцевого самоврядування в країнах Європейського Союзу мають достатнє нормативно-правове забезпечення власної діяльності [4]. В окремих країнах (Австрійської Республіки, Федеративної Республіки Німеччини, Республіки Польщі, Португальської Республіки, Республіки Словаччини, Республіки Угорщини) асоціації органів місцевого самоврядування закріплені у конституціях. Як правило, діяльність асоціацій регламентується національним законодавством. При цьому організаційно-правових засади деталізуються статутами 3 типовою регламентацією членства, прав та обов’язків членів; системи управління; компетенції, повноваження та способи їх реалізації; координація дій між членами; організаційне забезпечення роботи асоціації та іiі органів; контроль (самоконтроль) за діяльністю асоціації тощо.

Асоціації мають за мету, в першу чергу, відстоювання інтересів своїх членів через діалог на загальнонаціональному та місцевому рівнях. Організаційноправова форма їх є різною, незалежно від державного устрою, особливостей місцевого самоврядування. Право на асоціації реалізується в залежності від історії розвитку таких асоціацій: ряд країн мають автономні асоціації на кожному із рівнів місцевого самоврядування, в інших - єдина асоціація, яка об'єднує органи місцевого самоврядування всіх рівнів. Також $є$ практика подвійного членства та практика колективного (асоційованого) членства. С складні ієрархічні утворення, коли «парасолькова» національна асоціація має у складі асоціації різного рівня місцевого самоврядування і водночас є складовою міжнаціональної структури. У цілому типовими характеристиками асоціацій $є$ : добровільне та відкрите членство (як правило); правова регламентація діяльності статутними нормами; рівність права голосу, а рішення приймаються більшістю (як правило); добровільні членські внески; автономія і незалежність; добровільна робота та адвокація / представництво; можливість бути постачальниками послуг для своїх членів. Як 
правило, основна організаційна форма - юридичні особи. Найпопулярнішим $\epsilon$ об’єднання в асоціації первинної (базової) ланки місцевого самоврядування. Основною статтею доходів асоціацій $є$ членські внески. Поширена практика залучення грантових коштів. В окремих країнах $є$ практика співфінансування 3 державного бюджету певних програм асоціацій. А подекуди статути окремих асоціацій дозволяють надавати послуги своїм членам на платній основі. Для ефективного виконання власних повноважень важливим також є достатність інформаційних та комунікаціних ресурсів для забезпечення власної діяльності (вебсайти, сторінки у соціальних мережах, власні ЗМI, умови для видавництва та ведення онлайн-діалогу зі своїми членами тощо).

Право органів місцевого самоврядування об єднуватись в асоціації закріплено в Європейській хартії місцевого самоврядування, ратифікованій Україною у 1997 році. Стаття 10 Хартії визначає: “1. Органи місцевого самоврядування мають право, здійснюючи свої повноваження, співробітничати та в межах закону створювати консорціуми 3 іншими органами місцевого самоврядування для виконання завдань, що становлять спільний інтерес. 2. Право органів місцевого самоврядування бути членом асоціації 3 метою захисту i заохочення їхніх спільних інтересів, а також бути членом міжнародної асоціації органів місцевого самоврядування визнається кожною державою. 3. Органи місцевого самоврядування мають право на умовах, які можуть бути передбачені законом, співробітничати 3 органами місцевого самоврядування інших держав" [5].

Відповідно до статті 15 Закону України "Про місцеве самоврядування в Україні” органи місцевого самоврядування 3 метою більш ефективного здійснення своїх повноважень, захисту прав та інтересів територіальних громад можуть об'єднуватися в асоціації органів місцевого самоврядування та їх добровільні об'єднання, які підлягають реєстрації відповідно до Закону України "Про державну реєстрацію юридичних осіб, фізичних осіб - підприємців та громадських формувань” [6].

Закон України "Про асоціації органів місцевого самоврядування" від 16 квітня 2009 року № 1275-VI врегульовує порядок створення та припинення вітчизняних асоціацій, їх права та обов'язки, врегульовує питання взаємодії органів державної влади 3 асоціаціями тощо. Частина 1 статті 1 цього Закону визначає асоціації органів місцевого самоврядування та їх добровільні об'єднання як добровільні неприбуткові об'єднання, створені органами місцевого самоврядування 3 метою більш ефективного здійснення своїх повноважень, узгодження дій органів місцевого самоврядування щодо захисту прав та інтересів територіальних громад, сприяння місцевому та регіональному розвитку [7].

Відповідно до статті 3 Закону в Україні асоціації створюються із 
всеукраїнським та місцевим статусом. Але при цьому для створення асоціацій із всеукраїнськими статусом є умови об'єднання більше половини органів місцевого самоврядування відповідних територіальних рівнів. Місцева асоціація може бути створена не менш як трьома органами місцевого самоврядування.

На сьогодні в Україні є чотири асоціації з всеукраїнським статусом: три - це асоціації органів місцевого самоврядування базового рівня, одна - асоціація районних та обласних рад. Всеукраїнська асоціація органів місцевого самоврядування «Асоціація міст України», заснована у 1992 році під назвою Асоціація Рад народних депутатів міст України базового рівня. Наприкінці 2002 року їі було прийнято до Ради європейських муніципалітетів та регіонів. За період 1999-2001 роки було розбудовано мережу регіональних відділень асоціації, яких нині діє 25 у всіх регіонах України. Станом на грудень 2020 року асоціація налічує 909 членів (міста, селища і села, в яких проживає понад 80\% населення України).

Всеукраїнська асоціація сільських та селищних рад зареєстрована у Міністерстві юстиції України у вересні 2009 року. Нині це перейменована Всеукраїнська асоціація громад, до складу якої входять сільські, селищні ради, що представляють більш як 8500 територіальних громад, та понад 80\% населення, має 25 регіональних відділень та 7 виконавчих дирекцій в областях.

Асоціація об єднаних територіальних громад створена 25 листопада 2016 року. 3 моменту створення Асоціація вже об’єднала понад 490 нових громад з усіх регіонів України.

Всеукраїнська асоціація органів місцевого самоврядування «Українська асоціація районних та обласних рад», заснована у 1991 році під назвою Асоціація поріднених міст України, є майже ровесницями української незалежності. 3 того часу значних змін також зазнало нормативно-правове підгрунтя регламентації діяльності асоціації органів місцевого самоврядування, створювались асоціації різного статусу.

Повноваження асоціацій органів місцевого самоврядування визначені у статті 14 цього Закону. Відповідно до частини 2 статті 17 цього Закону однією 3 основних форм взаємодії асоціацій з державним органами є окрім іншого правові основи проведення консультацій асоціацій з органами виконавчої влади $з$ питань, зокрема, підготовки проекту закону про Державний бюджет України на відповідний рік. За асоціаціями закріплено право ініціювання консультацій 3 Верховною Радою України, Президентом України, Кабінетом Міністрів України 3 питань, що стосуються місцевого i регіонального розвитку. Участь у консультаціях гарантується і для місцевих асоціацій та регіональних відділень всеукраїнських асоціацій 3 місцевими органами виконавчої влади. Важливим $\epsilon$ право надання висновків асоціацій до проектів нормативно-правових актів 3 
питань, що стосуються місцевого і регіонального розвитку (як всеукраїнськими асоціаціями Президенту України, Верховній Раді України, Кабінету Міністрів України, центральним органам виконавчої влади, так і місцевими асоціаціями та регіональними відділеннями всеукраїнських асоціацій місцевим органам виконавчої влади).

Право на асоціації як таке не забезпечує спроможність. Важливим $\epsilon$ достатній обсяг повноважень, ефективний механізм їх реалізації та належне ресурсне забезпечення.

В. Полтавець зазначає, що “існують три умови для належного функціонування асоціації: чітке розуміння переваг міжмуніципального співробітництва для муніципалітетів; політична користь для політики міжмуніципального співробітництва 3 боку керівництва асоціації; достатні фінансові ресурси та кваліфікована кадри" [8]. У своїй доповіді “Роль асоціацій органів місцевого самоврядування - європейський досвід“ Магнус Ліллестрьом, ексnерm SKL International визначив, щзо “завдання, які, як правило, беруть на себе асоціації органів місцевого самоврядування, можна розділити на три групи:

1. Посилення потенціалу своїх членів шляхом розповсюдження інформації (включаючи роз'яснення відповідного законодавства), консультативні послуги, розробка методик та інструментів, діяльність 3 розбудови інституційного потенціалу тощо.

2. Представлення та захист інтересів своїх членів перед органами державної влади. Зазвичай це робиться як за допомогою структурованих, так і неформальних консультацій, петицій, участі в робочих групах, що розробляють відповідне законодавство тощо.

3. Забезпечення платформи для своїх членів для обміну досвідом та передовими практиками та створення культури, яка дає змогу членам узгоджувати спільні позиції з питань, що стоять на порядку денному держави, тобто мати можливість говорити в один голос" [9].

Висновки. Отже, право органів місцевого самоврядування при здійсненні повноважень створювати асоціації для виконання завдань, що становлять спільний інтерес, закріплено Європейською хартією місцевого самоврядування. Таке право закріплено на національному рівні європейських країн. В Україні питання асоціацій органів місцевого самоврядування регламентується спеціальним Законом України “Про асоціації органів місцевого самоврядування". Основними умовами спроможності асоціацій $\epsilon$ не лише забезпечення організаційно-правових засад, а й мотивація членів до об єднання та співпраця членів в рамках асоціації. Важливим фактором є достатнє ресурсне забезпечення, ефективна кадрова політика. Спроможність асоціацій органів місцевого самоврядування напряму залежить від всієї системи державної політики та 
забезпеченні прав місцевого самоврядування на самовизначення щодо добровільного об єднання органів місцевого самоврядування.

\section{Лimepamypa:}

1. Конкурентоспроможність регіонів України: Стан і проблеми (Аналітична доповідь Центру Разумкова). Національна безпека і оборона. 2008, № 4 (98). С. 12-30.

2. Крушановський С. Асоціації органів місцевого самоврядування України як елемент децентралізованої системи влади. Вісник Центральної виборчої комісії. 2008, №2 (12). С. 79-83.

3. Бодрова I.І. Добровільні об'єднання органів місцевого самоврядування як специфічний суб'єкт відносин місцевого самоврядування в Україні. Державне будівництво та місцеве самоврядування. 2003, вип. № 5. С. 45.

4. Особливості організаційно - правового забезпечення діяльності асоціацій органів місцевого самоврядування національного рівня в країнах Європейського Союзу. Презентація швейцарсько-українського проекту “Підтримка децентралізації в Україні” ДЕCПPO URL: http://komsamovr.rada.gov.ua/uploads/documents/42251.pdf (дата звернення 24.02.2021р.)

5. Свропейська хартія місцевого самоврядування. URL: http://zakon1.rada.gov.ua (дата звернення 24.02.2021 р.)

6. Про місцеве самоврядування в Україні: Закон України від 21 травня 1997 р. № 280/97BP URL: http://www.zakon.rada.gov.ua (дата звернення 24.02.2021р.)

7. Про асоціації органів місцевого самоврядування: Закон України від 16 квітня 2009 року № 1275-VI. URL: https://zakon.rada.gov.ua/laws/show/1275-17\#Text (дата звернення 24.02.2021р.).

8. Полтавець В. Форми добровільного об'єднання органів місцевого самоврядування як основа міжмуніципального співробітництва. Ефективність державного управління: зб. наук. праць. 2013, вип. 37. С. 295.

9. Магнус Ліллестрьом Роль асоціацій органів місцевого самоврядування - європейський досвід. URL: https://decentralization.gov.ua/news/13159 (дата звернення 24.02.2021р.).

10. Сало I. С. Асоціації органів місцевого самоврядування в системі узгодження інтересів на національному, регіональному та локальному рівнях. К. : НІСД, 2011. 39 с.

\section{References:}

1. Konkurentospromozhnist' regioniv Ukraïni: Stan i problemi (Analitichna dopovid' Centru Razumkova) [Competitiveness of the regions of Ukraine: Status and problems (Analytical report of the Razumkov Center)]. (n.d.). razumkov.org.ua. Retrieved from https://razumkov.org.ua/uploads/journal/ ukr/NSD159-160_2016_ukr.pdf [in Ukrainian].

2. Krushanovsky, S. (2008). Asociaciï organiv miscevogo samovrjaduvannja Ukraïni jak element decentralizovanoï sistemi vladi [Association of local governments of Ukraine as an element of a decentralized system of government]. Visnik Central'noï viborchoï komisiï - Bulletin of the Central Election Commission, 2, 79-83 [in Ukrainian].

3. Bodrova, I.I. (2003). Dobrovil'ni ob'ednannja organiv miscevogo samovrjaduvannja jak specifichnij sub' $k$ kt vidnosin miscevogo samovrjaduvannja v Ukraïni [Voluntary associations of local self-government bodies as a specific subject of local self-government relations in Ukraine]. Derzhavne budivnictvo ta misceve samovrjaduvannja - State building and local self-government, 5, 45 [in Ukrainian].

4. Osoblivosti organizacijno - pravovogo zabezpechennja dijal'nosti asociacij organiv miscevogo samovrjaduvannja nacional'nogo rivnja v kraïnah Evropejs'kogo Sojuzu. Prezentacija shvejcars'koukraïns'kogo proektu "Pidtrimka decentralizaciï v Ukraïni” DESPRO [Peculiarities of organizational 
and legal support of activity of associations of local self - government bodies of national level in the countries of the European Union. Presentation of the Swiss-Ukrainian project "Support to Decentralization in Ukraine" DESPRO (n.d.). komsamovr.rada.gov.ua. Retrieved from http://komsamovr.rada.gov.ua/uploads/documents/42251.pdf [in Ukrainian].

5. Evropejs'ka hartija miscevogo samovrjaduvannja [European Charter of Local SelfGovernment] (n.d.). zakon.rada.gov.ua. Retrieved from http://zakon1.rada.gov.ua [in Ukrainian].

6. Zakon Ukrainy «Pro misceve samovrjaduvannja v Ukraïni» [The Law of Ukraine «On local self-government in Ukraine»]. (n.d.). zakon.rada.gov.ua. Retrieved from http://www.zakon.rada.gov.ua [in Ukrainian].

7. Zakon Ukrainy «Pro asociaciï organiv miscevogo samovrjaduvannja» [The Law of Ukraine «On associations of local self-government bodies»]. (n.d.). zakon.rada.gov.ua. Retrieved from https://zakon.rada.gov.ua/laws/show/1275-17\#Text [in Ukrainian].

8. Poltavets, V. (2013). Formi dobrovil'nogo ob'ednannja organiv miscevogo samovrjaduvannja jak osnova mizhmunicipal'nogo spivrobitnictva [Forms of voluntary association of local governments as a basis for inter-municipal cooperation]. Efektivnist' derzhavnogo upravlinnja - Efficiency of public administration, 37, 295 [in Ukrainian].

9. Rol' asociacij organiv miscevogo samovrjaduvannja - evropejs'kij dosvid [The role of local government associations is the European experience]. (n.d.). decentralization.gov.ua. Retrieved from : https://decentralization.gov.ua/news/13159 [in Ukrainian].

10. Salo, I.S. (2011). Asociaciï organiv miscevogo samovrjaduvannja v sistemi uzgodzhennja interesiv na nacional'nomu, regional'nomu ta lokal'nomu rivnjah [Association of local governments in the system of coordination of interests at the national, regional and local levels]. Kyiv: NISD [in Ukrainian]. 